\title{
IMMUNOLOGICAL CHARACTERIZATION OF A DIABETOGENIC PROTEIN FROM BOVINE ADENOHYPOPHYSIS*
}

\author{
GeNe F. TUTWILER $\dagger$ \\ Department of Biological Chemistry, University of Michigan, Ann Arbor, Michigan, U.S.A.
}

(Received 2 August 1973)

\begin{abstract}
A diabetogenic protein isolated from bovine adenohypophysis which had previously been demonstrated to cause fasting hyperglycemia and decreased glucose tolerance in dogs and man is highly antigenic when injected into rabbits.

2. Immunoelectrophoresis and gel double diffusion studies did not provide evidence of multiple antibodies or antigens in the bovine diabetogenic protein: anti-bovine diabetogenic system.

3. Results of agar diffusion studies in which anti-bovine diabetogenic protein serum did not visibly react with homologous bovine serum proteins, serum albumin, ACTH or prolactin lend supporting evidence for the homogeneity of the reaction between bovine diabetogenic protein and its antiserum.

4. A comparative immunological study of diabetogenic proteins from various species was performed using agar double diffusion studies
\end{abstract}

\section{INTRODUCTION}

A DIABETOGENIC protein has been isolated from bovine (Louis et al., 1966; Tutwiler, 1973) ovine, porcine (Louis \& Conn, 1968) and human (Louis \& Conn, 1972) anterior pituitary glands. A similar substance has been isolated from the urine of patients with lipoatrophic diabetes (Louis et al., 1963) and diabetes mellitus patients with proteinuria (Louis \& Conn, 1969). The similarity of these substances has been based previously on the following: (a) the methods of isolation are essentially identical; (b) the active substance from all of the above sources has an isoelectric point of $4 \cdot 1$; and (c) regardless of source, the protein is capable of inducing hyperglycemia and insulin resistance when administered to either men or dogs.

The present studies were undertaken to characterize the purity of bovine diabetogenic protein using immunological techniques. In addition, the immunological similarity of bovine, ovine, porcine and human diabetogenic proteins was studied.

\section{MATERIALS AND METHODS}

\section{Immunization}

Crude bovine diabetogenic protein was prepared by a procedure described previously (Louis et al., 1966) and

* Supported in part by Grant No. GM00187 from N.I.H. to the Department of Biological Chemistry, University of Michigan.

$\uparrow$ Present address: Department of Biochemical Research, McNeil Laboratories, Inc., Camp Hill Road, Fort Washington, Pennsylvania 19034. was further purified utilizing Sephadex G-100 and G-100 superfine in two chromatography steps (Louis et al., unpublished results). Approximately $1 \mathrm{mg}$ of this purified protein was injected subcutaneously to three albino rabbits as an emulsion with complete Freund's adjuvant (Difco). The injections were given a total of seven times over a 6 -month period. The rabbit antisera were stored frozen until used.

\section{Immunodiffusion}

Immunodiffusion studies were carried out at $37^{\circ} \mathrm{C}$ by the method of Ouchterlony (1949). Petri dishes (50 $\times 12$ $\mathrm{mm}$; Falcon Plastics, Los Angeles) were coated with $4 \mathrm{ml}$ of a $1 \%$ agar solution. The $1 \%$ Noble agar (Difco) solution was prepared in $0.1 \mathrm{M}$ phosphate buffer, $\mathrm{pH} 7.2$, with $0.85 \%$ saline and $1 \%$ sodium azide. Precipitin ring tests (Kabat \& Mayer, 1961) were used to confirm the precipitin reactions on Ouchterlony plates. The antigens used were the following: bovine growth hormone (NIH-GH-B8), ovine prolactin (NIH-P-B1), bovine

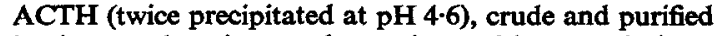
bovine; crude ovine, crude porcine and human pituitary diabetogenic protein (supplied by L. H. Louis, University of Michigan) and bovine serum albumin (Pharmacia).

\section{Immunoelectrophoresis}

Microscope slides coated with $1 \%$ Noble agar of $1 \%$ agarose (Sigma) were used for immunoelectrophoresis. The agar was prepared in barbital buffer $\mathrm{pH} 8.2$, ionic strength $0 \cdot 1$. Electrophoresis of antigens was for $2 \mathrm{hr}$ in barbital buffer ( $5 \mathrm{~mA} /$ plate). General methodology was taken from Crowle (1961) and Kabat (1968). Precipitin bands were stained with $0.5 \%$ Amido Schwarz in $0.045 \mathrm{~N}$ acetate buffer (10\% glycerine). 


\section{RESULTS}

Immunoelectrophoresis of bovine diabetogenic protein (BDP) in agarose (pH 8.2) with rabbit antiserum to BDP is shown in Fig. 1. A single precipitin line was obtained with approximately 0.2 and $1.2 \mu \mathrm{g}$ of protein and undiluted antiserum. The same result was obtained with ion-agar plates; however, BDP moved only slightly from the origin toward the anode.

With purified BDP and the rabbit antiserum, gel double diffusion studies did not provide evidence of multiple antibodies or antigens in the bovine DP: anti-BDP system. Figure 2 demonstrates a typical double diffusion Ouchterlony experiment. Only single precipitin bands which completely fused without detectable spur formation were observed, whether antisera reacted with the purified or crude diabetogenic protein. The antiserum is presumably reacting with the same substance in each case. The results here and in other studies have demonstrated that under the conditions employed approximately $0.1 \mu \mathrm{g}$ (in $20 \mu \mathrm{l}$ ) of BDP is the minimal amount which gives a visible precipitin reaction. Using double diffusion methods it was found that at concentrations greater than $2.0 \mu \mathrm{g}$, the precipitin band was faint and blurred. It is therefore assumed that at these amounts (Ouchterlony diffusion studies), the antigen is in excess to the anti-BDP (Kabat, 1968). The width of the precipitin bands varied with the concentration of BDP when the central well contained undiluted antiserum. The band was most intense at 0.8-1 $\mathrm{g}$ BDP.

A comparative immunological study of diabetogenic proteins from various species was performed using Ouchterlony tests. In these studies $30 \mu \mathrm{l}$ of undiluted antiserum was placed in the center well. In one of the peripheral wells of each agar plate, the purified BDP $(1 \mu \mathrm{g})$ was placed to serve as a positive precipitin control while BSA was used as negative control. The interaction of antiserum to BDP with DP preparations of various species is shown in Fig. 3. BDP and ovine DP cross-reacted to identify with anti-BDP. No precipitin reactions were even observed between the antiserum and the human or porcine diabetogenic protein in any dilutions (between 2 and $80 \mu \mathrm{g}$ ) tested over a period of 4 weeks.

When the same antiserum was tested against varying dilutions $\left(0, \frac{1}{10}, \frac{1}{100}, \frac{1}{1000}\right)$ of normal bovine serum, no precipitin bands were formed. Also, there was no reaction of the antiserum with bovine serum albumin (1-1000 mg). These findings gave supporting evidence for the specificity of the reaction between BDP and its antiserum.

Figure 4 shows the ability of 40 and $20 \mu \mathrm{g}$ of BGH to react with anti-BDP (lower amounts of BGH did not react). It also demonstrates the inability of $20 \mu \mathrm{g}$ ovine prolactin to react. Since ovine prolactin and bovine prolactin react to identity and to the same extent (Hayashida, 1962), studies with ovine prolactin are useful in excluding bovine prolactin as a contaminant. Ovine prolactin did not react with anti-BDP at concentrations between 0.8 and $200 \mu \mathrm{g}$. Also, bovine ACTH did not react with varying amounts between 4 and $60 \mu \mathrm{g}$.

\section{DISCUSSION}

The present study has shown that the diabetogenic protein from bovine adenohypophysis (BDP) is homogeneous and of high purity. It gave single precipitin lines with rabbit anti-BDP by immunoelectrophoresis (Fig. 1) and by double diffusion in two dimensions (Fig. 2). In addition, results of agar diffusion studies in which anti-BDP serum did not visibly react with homologous bovine serum proteins, serum albumin, ACTH or prolactin lend supporting evidence for the homogeneity of the reaction between bovine diabetogenic protein and its antiserum. Additional biological and physiochemical studies which conclusively demonstrate that BDP is of high purity and unique from other pituitary proteins are reported elsewhere (Tutwiler, 1970).

The results of Ouchterlony gel diffusion studies (Fig. 3) demonstrate that antibodies to bovine diabetogenic protein cross-react to identity with sheep diabetogenic protein but manifest no reaction with human or porcine diabetogenic proteins. Thus, bovine and sheep diabetogenic proteins appear to be closely related antigenically. On the other hand, the results indicate that a substance immunologically indistinguishable from bovine DP could not be detected in the diabetogenic protein preparations from human or porcine pituitaries. In preliminary results not reported here, diabetogenic protein from the urine of proteinuric diabetics also did not react with anti-BDP. This immunological species specificity has recently been confirmed using radioimmunoassay techniques (R. Knopf, personal communication).

The DP preparations, regardless of source, have similar isoelectric points $(\mathrm{pH} 4 \cdot 1)$ and isolation procedures; in addition, they are capable of inducing hyperglycemia and insulin resistance when administered to dogs and man. Paradoxically, the present studies have indicated that antibodies to BDP do not react with human or porcine diabetogenic proteins. If this antibody had been formed against the diabetogenic portion(s) of the molecule and if the diabetogenic portions of the bovine, porcine and human molecules are similar, the anti-BDP should have reacted with human and porcine DP. Since it did not this could suggest that the antigenic site of BDP and the portion of the BDP which is necessary for diabetogenic activity may be different.

Bovine growth hormone reacted to identity (Fig. 4) with anti-BDP in agar diffusion experiments. However, BDP was a better antigen since it takes 


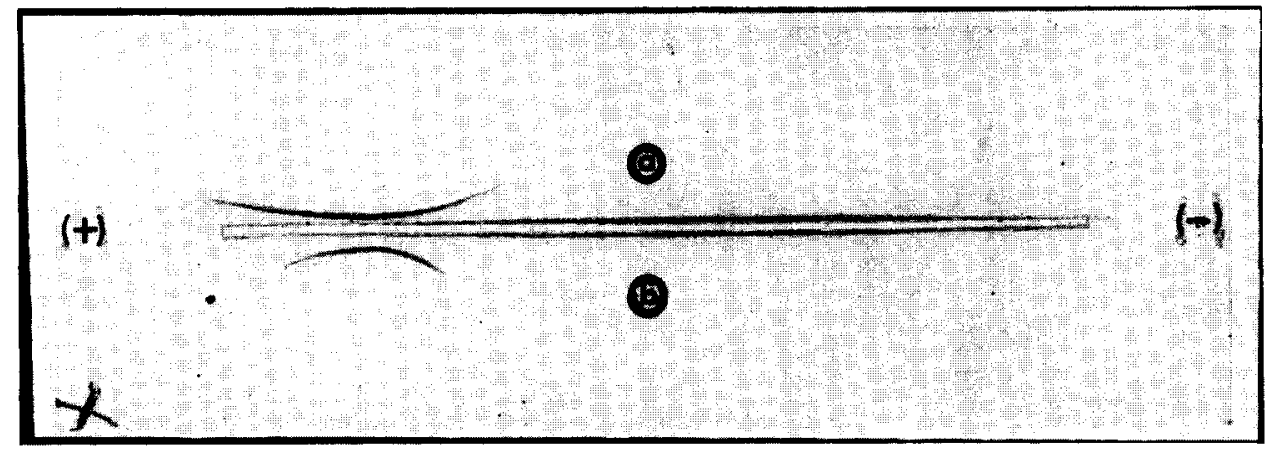

Fig. 1. Immunoelectrophoresis of bovine diabetogenic peptide on agarose. BDP $(600 \mu \mathrm{g} / \mathrm{ml})$ was placed in the top well (A) of the plate; BDP $(100 \mu \mathrm{g} / \mathrm{ml})$ was placed in the bottom well (B). Each well was filled with approximately $2 \mu \mathrm{l}$ of sample. Electrophoresis was for $2 \mathrm{hr}, \mathrm{pH} 8 \cdot 2$. The center well was filled with undiluted anti-BDP.

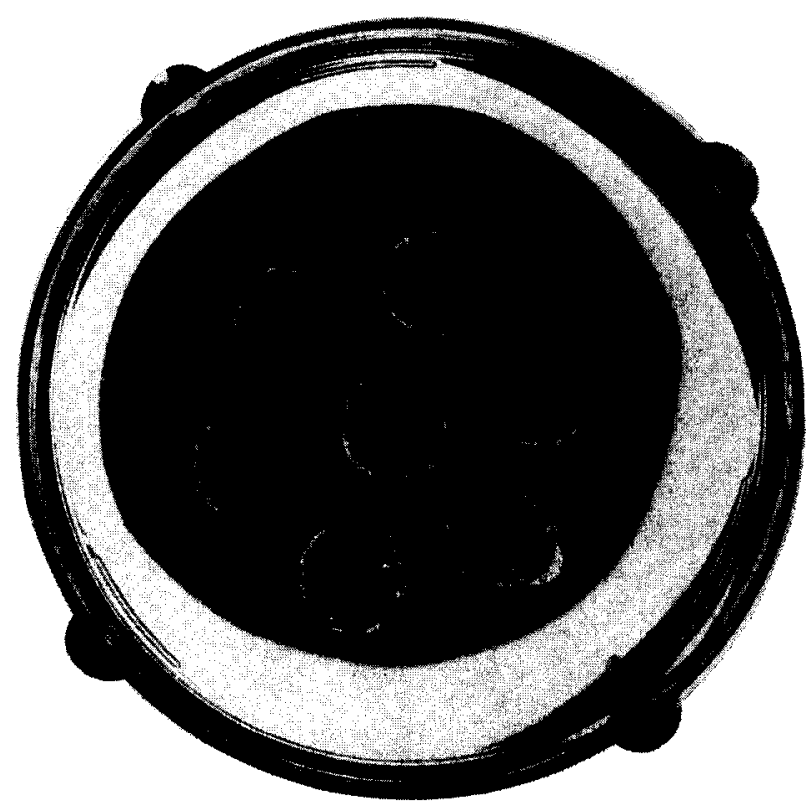

Fig. 2. Immunodiffusion of rabbit anti-bovine diabetogenic peptide serum against pure and crude BDP preparations. The central well contains $30 \mu \mathrm{l}$ of antiserum to BDP; wells 1 and 2 contain $8 \mu \mathrm{g}$ crude BDP; well 3, 0.1 $\mu \mathrm{g}$ pure; well $4,0 \cdot 2 \mu \mathrm{g}$ pure; well 5, $0 \cdot 8 \mu \mathrm{g}$ pure; and well $6,1 \mu \mathrm{g}$ purc BDP. 


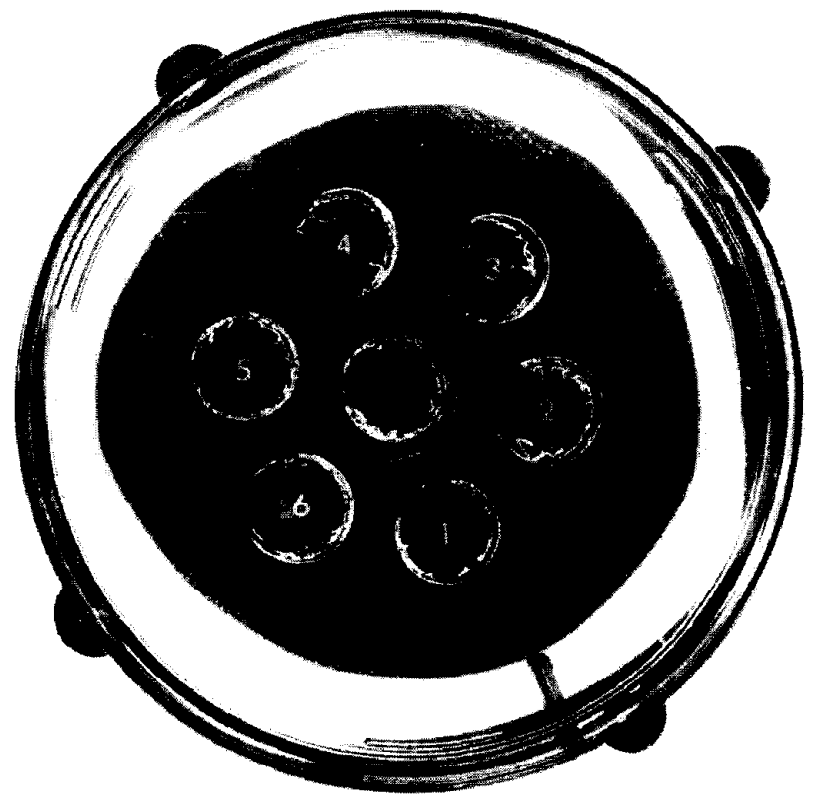

Fig. 3. The interaction of antiserum to bovine DP with DP preparations of various species, as determined by the Ouchterlony test. The central well contains antiserum to BDP; wells $I$ and 3 contain 1 and $40 \mu \mathrm{g}$ BDP and BSA respectively; well 2 contains $20 \mu \mathrm{g}$ ovine DP; well 4, $40 \mu \mathrm{g}$ human DP; wells 5 and 6 contain respectively 40 and $80 \mu \mathrm{g}$ porcine DP.

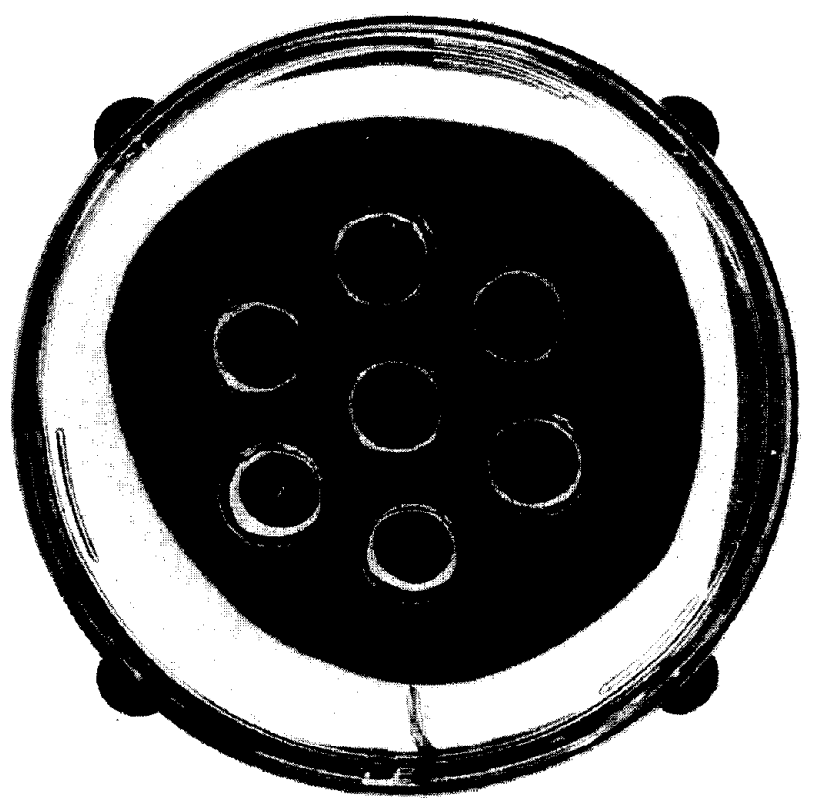

Fig. 4. The interaction of antiserum to bovine DP with bovine growth hormone and ovine prolactin, as determined by the Ouchterlony test. The central well contains antiserum to BDP; well 1 contains $1 \mu \mathrm{g}$ BDP; well 4, $10 \mu \mathrm{g}$ BSA; well 5, $20 \mu \mathrm{g}$ prolactin; wells 2,3 and 6 contain respectively 40,20 and $10 \mu \mathrm{g} \mathrm{BGH}$. 
about 100 times more $\mathrm{BGH}$ to manifest a reaction with anti-BDP. Previous studies (Tutwiler, 1970; Tutwiler \& Louis, 1971) indicate that the BDP preparations used for antibody production were not contaminated with BGH. Additional studies on the nature of this cross-reaction will be published in the next communication (Tutwiler, 1975).

\section{SUMMARY}

The diabetogenic protein from bovine adenohypophysis (BDP) was highly antigenic when injected into rabbits. BDP was found to be homogenous and of high purity by immunological techniques. A comparative immunological study of diabetogenic proteins from various species was performed using Ouchterlony tests. Bovine and ovine proteins were found to be closely related antigenically but are antigenically different from the human or porcine proteins.

Acknowledgements-I would like to thank Dr. $\mathbf{R}$. Knopf (Endocrinology and Metabolism Unit, University of Michigan Hospital, Ann Arbor, Michigan) for his work in the preparation of the antiserum.

\section{REFERENCES}

Crowle A. (1961) Immunodiffusion, p. 303. Academic Press, New York.

HAYASHIDA T. (1962) Immunological studies with lactogenic hormone (prolactin). Ciba Found. Collog. on Endoc. 14, 346-372.

KABAT E. A. (1968) Structural Concepts in Immunology and Immunochemistry, p. 1. Holt, Rinehart and Winston, New York.
Kabat E. A. \& MAYER M. M. (1961) Experimental Immunochemistry, p. 622. Charles C. Thomas, Springfield, Ill.

Louls L. H. \& ConN J. W. (1968) A diabetogenic polypeptide from hog and sheep adenohypophysis similar to that found in lipoatrophic diabetes. Metabolism 17, 475-484.

Louns L. H. \& ConN J. W. (1969) A urinary diabetogenic. polypeptide in proteinuric diabetic patients. Metabolism 18, 556-563.

Lous L. H. \& ConN J. W. (1972) Diabetogenic polypeptide from human pituitaries similar to that excreted by proteinuric diabetic patients. Metabolism 21, 1-9.

Louis L. H., ConN J. W. \& Minick M. C. (1963) Isolation and characterization of an insulin antagonist from urine. Metabolism 12, 867-886.

Louis L. H., ConN J. W. \& Minick M. C. (1966) A diabetogenic polypeptide from bovine adenohypophysis similar to that excreted in lipoatrophic diabetes. Metabolism 15, 309-324.

OUCHTERLONY O. (1949) Antigen-antibody reactions in gels. Acta Pathol. Microbiol. Scand. 26, 507-515.

TUTWILER G. F. (1970) Physiochemical and biological characterization of a diabetogenic peptide from bovine adenohypophysis. Thesis, University of Michigan.

TUTWILER G. F. (1973) Isolation of a non-growth promoting diabetogenic protein from bovine adenohypophysis. Int. J. Biochem. (Submitted for publication.)

TUTWILER G. F. (1975) Immunological cross-reaction of bovine growth hormone (NIH-GH-B8) with the antiserum to the bovine diabetogenic protein. Comp. Biochem. Physiol. 50A, 689-690.

TUTWILER G. F. \& LouIs L. H. (1971) Glycostatic effect of a diabetogenic non-growth promoting pituitary polypeptide. Int. J. Biochem. 2, 319-323.

Key Word Index - Diabetogenic protein; beef pituitary; homogeniety; immunoelectrophoresis. 